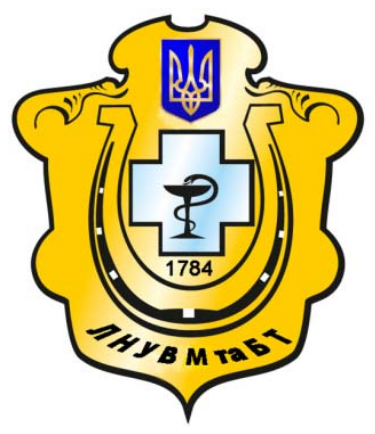

Науковий вісник Львівського національного університету ветеринарної медицини та біотехнологій імені С.3. Гжицького

Scientific Messenger of Lviv National University of Veterinary Medicine and Biotechnologies named after S.Z. Gzhytskyj

doi:10.15421/nvlvet6805

ISSN 2413-5550 print

ISSN 2518-1327 online

$\underline{\text { http://nvlvet.com.ua/ }}$

УДК 664.34:638.138

\title{
Перспективи створення нових видів майонезних продуктів, збагачених продуктами бджільництва
}

\author{
В.В. Вовк, М.3. Паска \\ vovk1805@gmail.com
}

\begin{abstract}
Львівський наџіональний університет ветеринарної медицини та біотехнологій імені С.3. Гжицького, вул. Пекарська, 50, м. Львів, 79010, Україна
\end{abstract}

В реаліях сьогодення, як ніколи гостро, стоїть проблема виробництва нових видів харчових продуктів. Продуктів, які безпосередньо призначені людям різних вікових груп та, водночас, мають збалансований склад підвищеної харчової та біологічної цінності, яка відповідає потребам організму.

В основу наших досліджень покладено завдання оптимізаиії рецептури майонезу за рахунок додавання продуктів бджільничтва. Багатокомпонентний склад і структура майонезів дає широкі можливості для збагачення їх всіма видами функціональних інгредієнтів. Такий продукт бджільництва, як бджолине обніжжя (пилок), являє собою збалансований природою, вітамінно-мінеральний, енергетичний комплекс. Він є практично найбагатшим джерелом вітамінів групи $A, E$, $C, D$, РP, K, мас у своєму складі калій, залізо, мідь, кобальт, кальиій, фосфор, магній, иинк, марганець, хром, йод.

Клінічні тести бджолиного обніжжя (квіткового пилку), дозволили переконатися в його широкій $і$ багатогранній дії на організм як здорової так і хворої людини. Квітковий пилок добре поєднується з молочними продуктами за рахунок свого кольору, підібраного для внесення, надає красивий, ніжний відтінок і пряно-медовий смак, ще при правильно підібраній рецептурі позитивно впливає на органолептичні показники готового продукту.

Маслянка - вторинна молочна сировина, яку отримують при виробництві верикового масла різними способами виробництва. Вона є високоякісною дієтичною молочною сировиною, що зумовлює ї̈ використання тільки для виробництва харчових продуктів. На відміну від знежиреного молока маслянка містить білки оболонок жирових кульок, які є комплексом білків і ферментів. Ці білки характеризуються високим вмістом сірковмісних амінокислот-метіоніну цистину $і$ иистеїну, які мають виражені протисклеротичні властивості. У проиесі виробництва майонезу основним обладнанням технологічної лінії є гомогенізатори, які повинні забезпечувати створення гомогенних, тонкодисперсних емульсій із заданим розміром частинок. Використання вакуум виробничої установки Fryma Когита МаххD, дозволяє отримувати якісні майонезні продукти при менших енергетичних затратах.

Ключові слова: олійно-жирова промисловість, майонез, рецептура, продукти бджільництва, бджолине обніжжя, пилок, маслянка, енергозберігаюче обладнання, Fryma Koruта МаххD.

\section{Перспективы создания новых видов майонезных продуктов, обогащенных продуктами пчеловодства}

\author{
В.В. Вовк, М.З. Паска \\ vovk1805@gmail.com

\begin{abstract}
Львовский национальный университет ветеринарной медицины и биотехнологий имени С.3. Гжицякого, ул. Пекарская, 50, г. Львов, 79010, Украина
\end{abstract}

Сегодня, как никогда остро, стоит проблема производства новых видов пищевых продуктов. Продуктов, которые непосредственно предназначены людям разных возрастов и одновременно имеют сбалансированный состав повышенной пищевой и биологической цеености, соответствующей потребностям организма. В основу наших исследований, положена

\footnotetext{
Citation:

Vovk, V.V., Paska, M.Z. (2016). Prospects of creation of new types of the mayonnaise foods enriched by foods of beekeeping. Scientific Messenger LNUVMBT named after S.Z. Gzhytskyj, 18, 2(68), 27-31.
} 
задача оптимизации речептуры майонеза за счет добавления продуктов пчеловодства. Многокомпонентный состав и структура майонезов дает широкие возможности для обогашения их всеми видами функииональных ингредиентов.

Такой продукт пчеловодства, как пчелиная обножка (пыльияа), представляет собой сбалансированный природой, витаминно-минеральный, энергетический комплекс. Пчелиная обножка - практически самый богатый источник витаминов группь $A, E, C, D, P P, K$, имеет в своем составе калий, железо, медь, кобальт, кальций, фосфор, магний, циинк, марганеи, хром, йод. Клинические тесты пчелиной обножки (иветочной пыльцы), позволили убедиться в ее цироком и многогранном действие на організм, как здорового, так и больного человека. Цветочная пыльца хорочо сочетается с молочньли продуктами за счет своего цвета, подобранного для внесения, предоставляет красивый, нежный оттенок и пряно-медовый вкус, что при правильно подобранной рецептуре положительно влияет на органолептические показатели готового продукта. Маслянка - вторичное молочное сырье, которое получают при производстве сливочного масла различныли способами производства. Она является высококачественным, диетическим молочным сырьем, что приводит к ее использования только для производства пищевых продуктов. В отличие от обезжиренного молока маслянка содержит белки оболочек жировых шариков, которые являются комплексом белков и ферментов. Эти белки характеризуются высоким содержанием серосодержащих аминокислот-метионина цистина и цистеина, которые обладают выраженными противосклеротическими свойствами. В проиессе производства майонеза основным оборудованием технологической линии являются гомогенизаторы, которые должны обеспечивать создание гомогенных, тонкодисперсных эмульсий с заданным размером частии.

Использование установки Fryma Когита МаххD, позволяет получать качественные майонезные продукты при меньиих энергетических затратах.

Ключевые слова: масложировая промышленность, майонез, рецептура, продукть пчеловодства, пчелиная обножка, пьльича, маслянка, энергосберегающее оборудование, Fryma Koruma MaxxD.

\title{
Prospects of creation of new types of the mayonnaise foods enriched by foods of beekeeping
}

\author{
V.V. Vovk, M.Z. Paska \\ vovk1805@gmail.com

\begin{abstract}
Lviv National University of Veterinary Medicine and Biotechnologies named after S.Z. Gzhytskyi, Pekarska Str., 50, Lviv, 79010, Ukraine
\end{abstract}

In realities of present time, as never sharply, the problem of production of new types of food foods stands. Foods, that is directly appointed to the people of the differentage-related groups and, at the same time, have the balanced composition of an increase food and biological value that answers the necessities of organism. In basis of our researches a task, to optimize compounding of mayonnaise is fixed due to addition of foods of beekeeping.

Multicomponent composition and structure of mayonnaises give an wide opportunities for enriching of them, all types off unctional ingredients. Such product of beekeeping, as a bee pollen, shows a balanced by nature, vitamin-mineral, power complex. He is practically the richest source of vitamins of group $A, E, C, D, P P, K$, has in the composition potassium, iron, copper, cobalt, calcium, phosphorus, magnesium, zinc, manganese, chrome, iodine. Clinical tests of bee pollen, allowed to make sure in his wide and many-sided operating on an organism, of healthy and also sick man. A bee pollen well combines with dairies due to the color neat forbringing, gives a beautiful, tender tint and spicily-honey taste that at the correctly neat compounding positively influences on the organoleptic indexes of the prepared product. Oiler is secondary suckling raw material that is got at the production of dairy butter in number of different ways by production. She is high-quality dietary suckling raw materialthat predetermines her use only for the production of foods. Unlike fat free milk oiler contains proteins of shells offatty marbles, that are the complex of proteins and enzymes. These squirrel are characterized by high maintenance of sulfur-containing amino acids-methionine cistine and cystein, that are expressed antisclerotic characteristics. In the process of production of mayonnaise to the basice quipments of technological line there are blenders that must provide creation of the homogeneous, micronize demulsions with the set size of particles. The use is a vacuum of the productive setting of FrymaKoruma MaxxD, allows to get quality mayonnaise foods at less power expenses.

Key words: oily-fatty industry, mayonnaise, compounding, foods of beekeeping, bee pollen, oiler, energykeeping equipment, Fryma Koruma MaxxD.

\section{Ветуп}

Основою функціонування життєдіяльності організму є постійне надходження з їжею поживних речовин: білків, жирів, вуглеводів, вітамінів та мінеральних речовин. Всі ці необхідні елементи живлення тісно взаємодіють між собою і від їх співвідношення значною мірою залежить функціональний стан організму (Earle et al., 2001; Paska et al., 2013; Paska et al., 2014; Paska and Vovk, 2015).

Багатокомпонентний склад і структура майонезів дає широкі можливості для збагачення їх всіма видами функціональних інгредієнтів. Одними 3 таких функціональних інгредієнтів $є$ квітковий пилок та його продукт перга. Бджолине обніжжя (пилок), являє собою збалансований природою, вітамінномінеральний, енергетичний комплекс. Квітковий пилок $\epsilon$ практично найбагатшим джерелом вітамінів групи А, Е, C, D, РP, K, він володіє антимікробною, противірусною, протизапалювальною, інгібіторною дією на живий організм. Пилок застосовують у суміші 3 медом в профілактиці і комплексному лікуванні серцево-судинних захворювань - міккарду, вад серця, ревматизму, гіпертонічної хвороби, атеросклерозу (Shanchenko and Shcherbyn, 2005).

Наявність в обніжжі деяких антибіотиків і тритерпенових кислот вчені зв'язують 3 протизапальною i регенеруючою діями пилку при захворюваннях шлунково-кишкового тракту (гастритів, колітів, язви), 
печінки (гепатитів), в хірургічній практиці, дерматології, косметиці (Shanchenko and Shcherbyn, 2005).

\section{Матеріал і методи досліджень}

В основу досліджень покладено завдання оптимізації стандартної рецептури майонезу за рахунок вне- сення продуктів бджільництва (бджолиного обніжжя), та застосування нового, енергозберігаючого обладнання Fryma Koruma MaxxD.

Рецептура в наших дослідженнях включає заміну певного відсотка емульгатора на бджолиний пилок (таблиця 1).

\begin{tabular}{|l|c|c|c|c|c|}
\multicolumn{2}{|c|}{ Компоненти } & \multicolumn{5}{c|}{ Вміст (у \%) } \\
\cline { 2 - 6 } & Контроль & 1 зразок & 2 зразок & 3 зразок & 4 зразок \\
\hline $\begin{array}{l}\text { Олія рослинна рафінована, дезо- } \\
\text { дорована }\end{array}$ & 65.4 & 65.4 & 65.4 & 65.4 & 65.4 \\
\hline Сухе знежирене молоко & 1.6 & 1.6 & 1.6 & 1.6 & 1.6 \\
\hline Маслянка пастеризована & 10 & 10 & 10 & 10 & 10 \\
\hline Емульгатор & 5 & 2.6 & 3 & 2 & 2,2 \\
\hline Бджолиний пилок & 0 & 2.4 & 2 & 3 & 2.8 \\
\hline Гірчичний порошок & 0.65 & 0.65 & 0.65 & 0.65 & 0.65 \\
\hline Цукор пісок & 1.5 & 1.5 & 1.5 & 1.5 & 1.5 \\
\hline Сіль кухонна & 1.1 & 1.1 & 1.1 & 1.1 & 1.1 \\
\hline Сода питна & 0.05 & 0.05 & 0.05 & 0.05 & 0.05 \\
\hline Оцтова кислота 80\% & 0.65 & 0.65 & 0.65 & 0.65 & 0.65 \\
\hline Вода питна & 14.05 & 14.05 & 14.05 & 14.05 & 14.05 \\
\hline Всього & 100 & 100 & 100 & 100 & 100 \\
\hline
\end{tabular}

Квітковий пилок, який випускається по ДСТУ 3127-95 і використовується в якості харчової добавки, має тверду консистенцію і розмір зерен від 1 до 4 мм. (Earle et al., 2001). Для рівномірного розподілу обніжжя по всій масі майонезу його необхідно розчинити до утворення дисперсного розчину. Тому були проведені дослідження по виборі розчинника і умов розчинення квіткового пилку.

В якості розчинника були використані такі середовища, як вода питна і маслянка пастеризована.

Попередньо була вибрана температура розчинення квіткового пилку. В результаті проведених досліджень встановлено, що при температурі розчинення $30^{\circ} \mathrm{C}$ у квітковому пилку зберігаються біологічно активні речовини.

Розчинники підігрівали до температури $30^{\circ} \mathrm{C}$, засипали гранули квіткового пилку і вели процес розчинення при інтенсивному перемішуванні. Результати досліджень наведено у діаграмі 1.

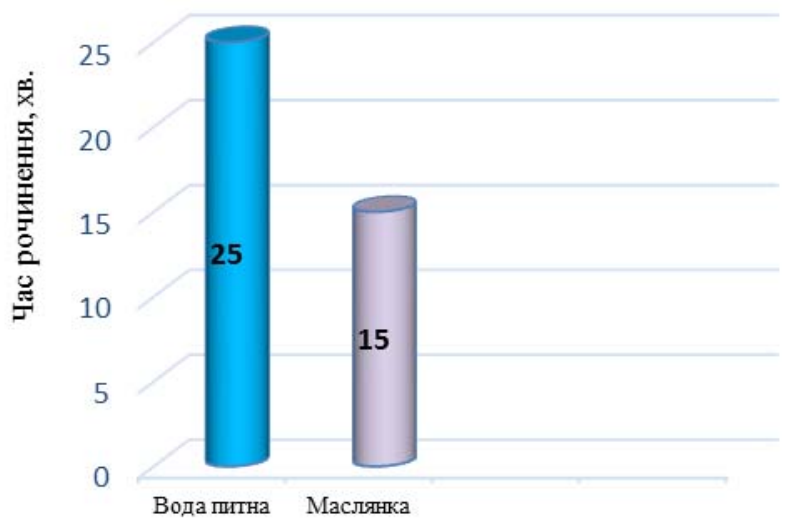

Рис. 1. Вплив виду розчиннника на час розчинення квіткового пилку
Як видно з представлених даних, в залежності від розчинника час розчинення виявився різним. Найбільш інтенсивно розчинення гранул пилку проходить у маслянці пастеризованій.

Встановлена оптимальна температура розчинення $30{ }^{\circ} \mathrm{C}$, час розчинення при цьому 15 хвилин.

Для визначення оптимальної кількості маслянки пастеризованої були проведені дослідження структурно-механічних властивостей майонезу після внесення різних кількостей розчинника.

Оптимальна кількість маслянки пастеризованої в якості розчинника, яка надає продукту більш в'язку структуру складала $10 \%$.

Оскільки в розчиненій маслянці присутні домішки (фрагменти рослин, з яких бджоли збирають пилок, волоски опушення самої комахи і т. д.), то опісля були проведені дослідження з використанням бінокулярної лупи для визначення розмірів отворів фільтру. Встановлено, що для фільтрування розчиненого у маслянці квіткового пилку необхідно використовувати фільтр з розміром отворів 1,0 мм.

Квітковий пилок добре поєднується з молочними продуктами за рахунок свого кольору, підібраного для внесення, надає красивий, ніжний відтінок і пряномедовий смак, що при правильно підібраній рецептурі позитивно впливає на органолептичні показники готового продукту.

Маслянка - вторинна молочна сировина, яку отримують при виробництві вершкового масла різними способами виробництва. Її поділяють на солодку і кислу.

Вихід маслянки залежить від організації технологічного процесу і зумовлений масовою часткою жиру у вихідних вершках та вмістом плазми у маслі.

Під час промислової переробки молока у маслянку переходить 14\% молочного жиру, 99,4\% білків, 99,4\% лактози, 99,6\% мінеральних солей, 72,8\% сухої речовини. 
Маслянка $\epsilon$ високоякісною дієтичною молочною сировиною, що зумовлює іï використання тільки для виробництва харчових продуктів.

На відміну від знежиреного молока маслянка містить білки оболонок жирових кульок, які є комплексом білків і ферментів. Ці білки характеризуються високим вмістом сірковмісних амінокислот-метіоніну цистину і цистеїну, які мають виражені протисклеротичні властивості.

Корисні властивості білків підсилюються завдяки їх сполученню $з$ вітамінами, на які багата маслянка. Особливо з білками з'єднані вітаміни групи В. У маслянці у великій кількості міститься холін, який необхідний для росту і розвитку організму. Його дія найбільше проявляється у комплексі 3 метіоніном (Nechaev et al., 2000; Shanchenko and Shcherbyn, 2005; Tsisaryk et al., 2014).

У процесі виробництва майонезу основним обладнанням технологічної лінії $є$ гомогенізатори, які повинні забезпечувати створення гомогенних, тонкодисперсних емульсій із заданим розміром частинок (Earle et al., 2001; Paska, 2015).

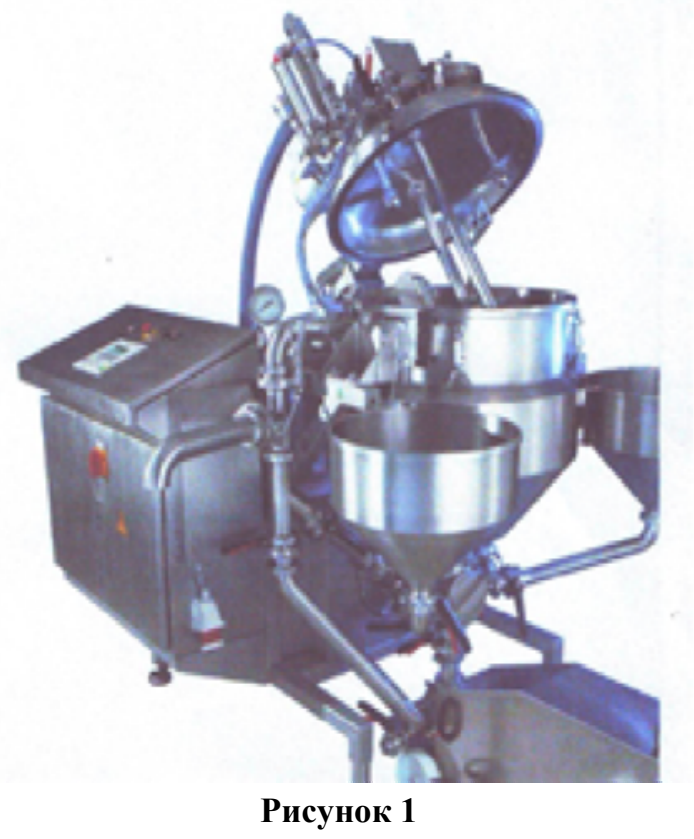

Такий гомогенізатор (Рисунок 2, 3) представлений фірмою Fryma Koruma і має назву MaxxD. Це модульна система для виробництва емульсій і суспензій 3 широким діапазоном в'язкості.

Такий гомогенізатор призначений як для харчової промисловості (виробництво майонезів, соусів), так і для косметичної (виробництво емульсій, лосьйонів, гелі) та хімічної (виробництво фотоемульсій і чорнил).

\section{Перевагами установки с:}

1. Високоефективне виробництво 3 низькими експлуатаційними затратами і підвищеною продуктивністю.

2. Попередньо встановлені параметри гарантують постійну якість продукту.

3. Кінцевий продукт стійкий, однорідний, не містить повітря.
4. Універсальність (установка має можливість виготовляти велику різноманітність продуктів різних об'ємів та за різними технологіями).

Гомогенізатор заснований на принципі багатокамерної системи ротор / статор, яка є оптимальним рішенням для виготовлення емульсій.

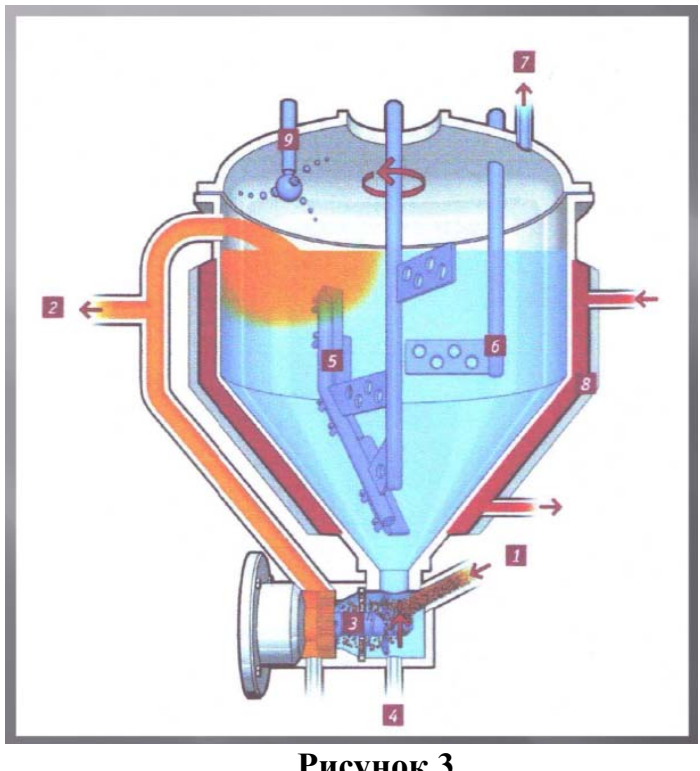

Рисунок 3

$\begin{array}{ll}1 . & \text { Подача продукту. } \\ 2 . & \text { Вихід продукту. } \\ 3 . & \text { Гомогенізатор } \\ 4 . & \text { Вихід залишків. } \\ 5 . & \text { Система змішування. } \\ 6 . & \text { Зменшувач потоку. } \\ 7 . & \text { Вакуумна система. } \\ 8 . & \text { Нагрівання / охолодження. } \\ 9 . & \text { СІР-форсунка . }\end{array}$

За допомогою насоса продукт попадає в першу камеру, де проходить попереднє змішування продукту. Потім продукт потрапляе в зубчату систему статор / ротор. Хороша якість продукту досягається завдяки великому значенню поперечної сили, виникаючої в зазорі між ротором та статором, і високої турбулентності на виході з ротора. При виготовленні емульсії розмір жирової кульки досягає 1 мкм. При диспергуванні суспензії, порошки і тверді речовини зволожуються, гомогенізуються до того часу, поки не буде отримано потрібну кількість продукту.

\section{Висновки}

Встановлено, що додавання бджолиного обніжжя у майонезну пасту, а також використання маслянки, як розчинника пилку, створює усі умови для розробки нових видів майонезу, які будуть надавати продукту задані властивості.

Перспективи подальших досліджень. Подальші дослідження спрямовані на дослідження органолептичних, фізико-хімічних, реологічних та біологічних властивостей отриманого продукту, а також прове- 
дення економічної оцінки виробництва майонезу, збагаченого бджолиним пилком.

\section{Бібліографічні посилання}

Paska, M.Z., Zhuk, O.I, Martyniuk, I.O., Drachuk, U.R (2013). Innovative technologies in the oil and fat industry. Scientific Messenger LNUVMBT named after S. Z. Hzhytskoho. 3(57), 15, 102-116.

Paska, M. Z., Zhuk, O. I., Galuh, B.I., Drachuk, U.R. (2014). Energy efficiency in modern conditions in enterprises oil and fat industry. Scientific Messenger LNUVMBT named after S.Z. Hzhytskoho. 16, 3(60), 129-136.

Paska, M.Z. (2015). The use of innovative equipment Fryma Koruma MaxxD, in the production of mayonnaise. East European Journal of advanced technologies. Kharkyv, 2/10(74).
Paska, M. Z., Vovk, V.V. (2015). The main technological aspects of bee pollen in the production of mayonnaise. Status and prospects of food science and industry: materials of international scientific conference. Abstracts (Ternopil 8-9 October 2015). MON Ukraine, TNTU Ivan Pul'uj - Ternopil: edition TNTU Ivan Pul'uj, 84-86.

Nechaev, A.P., Kochetkova, A.A., Nesterov, I. (2000). Mayonnaise. Spb .: HYORD.

Earle, M., Earle, R., Anderson, A. (2001). The knowledge base for product development. Food Product Development, Cambridge, Woodhead Publishing Ltd. 149-193.

Shanchenko, N.I., Shcherbyn, O.B. (2005). Honey and bee pollen. Cherkasy gate, Ukraine.

Tsisaryk, O.J., Myhaylytska, A.R., Slyvka, N.B., Turchin, I.M. (2014). Technology of dairy products from recycled materials: Textbook. Lviv, LeaguePress.

Стаття надійшла до редакиії 30.09.2016 